\title{
PERAN MEDIA SOSIAL DALAM MENINGKATKAN PARTISIPASI PEMILIH PEMULA DI KALANGAN MAHASISWA FAKULTAS ILMU SOSIAL UNIVERSITAS NEGERI SEMARANG
}

\author{
Nugraheni Arumsari ${ }^{{ }}$, Wenny Eka Septina ${ }^{2}, \quad$ Iwan Hardi Saputro ${ }^{3}$,
}

Fakultas Ilmu Sosial , Universitas Negeri Semarang

\section{Info Artikel}

Sejarah Artikel:

Disubmit April 2020

Direvisi Mei 2020

Diterima Mei 2020

Keywords: Kampanye presiden, Media Sosial, Pemilih Pemula, Partisipasi

\begin{abstract}
Abstrak
Indonesia merupakan negara demokrasi yang menjunjung tinggi kebebasan hak asasi manusia dan juga dalam mengemukakan pendapat di muka umum. Dalam negara demokrasi inilah Pemilihan Umum atau Pemilu masih dianggap sebagai bentuk partisipasi masyarakat yang bentuknya paling konkret dalam penyelenggaraan pemerintahan. Salah satunya yaitu bentuk partisipasi politik melalui media sosial yang banyak digunakan oleh kalangan remaja yang dapat dikatakan sebagai pemilih pemula. Penelitian ini bertujuan untuk menjelaskan peran media sosial dalam meningkatkan partisipasi pemilih pemula pada pemilihan presiden tahun 2019. Metode penelitian ini bersifat deskriptif analisis, ialah untuk menggambarkan, menganalisis dan menginterpretasikan data. Tehnik pengambilan data dengan cara: observasi, wawancara, kuesioner dan FGD (Focus Group Discutions). Hasil penelitian menunjukkan bahwa penggunaan media sosial di kalangan pemilih pemula untuk mengakses informasi mengenai pemilu, yaitu Instagram menempati urutan pertama yaitu $77,6 \%$ selanjutnya terdapat WhatApps, Youtube dan Twitter, sedangkan faktor-faktor yang mempengaruhi partisipasi pemilih pemula melalui media sosial dipengaruhi oleh modernisasi, pengaruh kaum intelektual dan komunikasi massa modern dan keterlibatan pemerintah dalam urusan sosial, ekonomi dan kebudayaan.
\end{abstract}

\begin{abstract}
Indonesia is a democratic country that upholds freedom of human rights and also in expressing opinions in public. In this democratic country General Election or Election is still considered as the most concrete form of community participation in the administration of government. One of them is a form of political participation through social media that is widely used by teenagers who can be regarded as novice voters. This study aims to explain the role of social media in increasing voter turnout in the 2019 presidential election. The research method is descriptive analysis, which is to describe, analyze and interpret data. Data collection techniques by: observation, interviews, questionnaires and FGD (Focus Group Discutions). The results showed that the use of social media among novice voters to access information about the election, namely Instagram ranks first, namely $77.6 \%$, then there are WhatApps, Youtube and Twitter, while the factors that influence voter participation through social media are influenced by modernization, the influence of intellectuals and modern mass communication and government involvement in social, economic and cultural affairs.
\end{abstract}

(C) 2020Universitas Negeri Semarang

\footnotetext{
Alamat korespondensi:

Contoh:

Gedung C4 Lantai 1 Jurusan PKn UNNES

Kampus Sekaran, Gunungpati, Semarang, 50229

E-mail: nugraheni.arum@mail.unnes.ac.id
} ISSN 2252-7133 


\section{PENDAHULUAN}

Indonesia merupakan negara demokrasi yang menjunjung tinggi kebebasan hak asasi manusia dan mengemukakan pendapat di muka umum. Kebebasan berpendapat di Indonesia dilindungi oleh undang-undang. Oleh karena itu masyarakat di Indonesia mempunyai hak untuk menyampaikan aspirasi, menuntut dan mendukung kebijakan pemerintah, serta melakukan kontrol terhadap kebijakan yang dikeluarkan oleh pemerintah.

Dalam negara demokrasi inilah Pemilihan Umum atau Pemilu masih dianggap sebagai bentuk partisipasi masyarakat yang bentuknya paling konkret dalam penyelenggaraan pemerintahan. Yang salah satunya yaitu bentuk partisipasi melalui media sosial yang banyak digunakan oleh kalangan remaja yang dapat dikatakan sebagai pemilih pemula. Hal ini selaras dengan data yang dikeluarkan oleh Kementerian Dalam Negeri (Kemendagri) yang mencatat ada 5.035.887 orang pemilih pemula pada Pemilu 2019. Data ini masuk dalam Daftar Penduduk Pemilih Potensial Pemilu (DP4) (https://news.detik.com/berita/d-4215354/ada5-juta-pemilih-pemula-di-pemilu-2019).

Begitu pula dengan adanya perkembangan teknologi informasi, menunjukkan adanya pergeseran arah penggunaan media komunikasi, yang semula berbentuk klasik (media elektronik dan cetak) kini mengalami perubahan menuju media baru (new media) yang berbasis internet sebagai saluran akses ke media sosial. Media sosial digunakan sebagai salah satu strategi komunikasi politik dalam pemilihan umum.

Media sosial diakui memiliki pengaruh yang kuat pada perilaku partisipasi politik, beberapa studi yang dilakukan untuk melihat perbandingan lintas nasional yang mengarah pada pemberitaan keterlibatan politik dan dampaknya bagi masyarakat (Saldana, dkk. 2015). Pentingnya mengkomunikasikan aktifitas komunikasi atau gagasan politik inilah yang menjadikan media khususnya media sosial sebagai alat yang sangat penting. Keterkaitan media dan politik menjadi hal yang paling utama. Karena kita mengetahui bahwa peran media sosial dalam pengaruhnya di dunia politik sangat terkait dengan perilaku politik dan jumlah suara yang didapatkan (Arumsari, 2018).

Partisipasi politik memiliki peran penting dalam proses pemilihan umum. Tahun 2019 rakyat Indonesia menyelenggarakan Pesta Demokrasi atau Pemilu untuk memilih presiden. Jenis pemilih yang perlu diperhatikan tingkat partisipasi politik pemilihnya adalah bagi para pemilih pemula karena pemilih pemula di Indonesia pada umumnya mempunyai jumlah yang tidak sedikit, akan tetapi pemilih pemula juga masih dianggap tingkat kesadaran berpolitik atau pengetahuan tentang pendidikan politiknya masih rendah sehingga dikhawatirkan akan menurunkan tingkat partisipasi politik pada pemilu kali ini. Mengingat pentingnya partisipasi politik pemilih pemula dalam pemilihan umum, maka perlu dilakukan kajian penelitian tentang PERAN MEDIA SOSIAL DALAM MENINGKATKAN PARTISIPASI PEMILIH PEMULA DI KALANGAN MAHASISWA FAKULTAS ILMU SOSIAL UNIVERSITAS NEGERI SEMARANG

\section{METODE}

Penelitiaan ini menggunakan metode kualitatifdeskriptif. Metode kualitatif adalah disebut pula metode penelitian naturalistik karena penelitiannya dilakukan pada kondisi yang alamiah (Sugiyono, 2014: 13). Pendekatan deskriptif adalah suatu penelitian yang didasarkan pada data yang ada atau penyelidikan yang bertujuan pada pemecahan masalah (Winarno, 2002: 175). Dengan demikian, pendekatan kualitatif deskriptif adalah penelitian yang menggambarkan data kualitatif sebagaimana adanya, dan kemudian data tersebut dianalisis makna dibalik fakta yang tampak. Penelitian ini melibatkan 814 mahasiswa baru yang berada di lingkungan Fakultas Ilmu Sosial Universitas Negeri Semarang. Populasi sasaran dalam penelitian ini adalah pemilih pemula yang merupakan mahasiswa baru tingkat pertama yang berusia antara 18-21 tahun. Penarikan sampel berdasarkan teknik purposif (purposive sampling) kepada mahasiswa baru yang sudah memenuhi 
syarat untuk memilih pada pemilihan umum presiden 2019. Setiap Jurusan akan diwakili oleh 10-15 siswa yang seluruhnya terdapat 85 sample yang mewakili dari 8 Jurusan yang terdapat di Fakultas Ilmu Sosial.

Teknik pengumpulan data menggunakan instrumen; (1) observasi, yaitu mengadakan pengamatan secara langsung, (2) kuesioner, bersifat tertutup, dan (3) Focus Group Discussion (FGD) dengan tujuan untuk mendapatkan data dan informasi yang mendalam. Adapun data sekunder diperoleh dari literatur-literatur yang terkait dengan kajian sesuai dengan penelitian.

\section{PEMBAHASAN}

Keberhasilan media sosial dalam meningkatkan partisipasi pemilih pemula di kalangan mahasiswa Fakultas Ilmu Sosial di Universitas Negeri Semarang tentunya tidak terlepas dari peran media sosial itu sendiri yang banyak sekali digunakan oleh netizen untuk mendapatkan informasi terkait dengan adanya pemilihan presiden 2019 di Indonesia. Media sosial yang akan dibahas kali ini meliputi Facebook, Tweeter, Instagram, Youtube, Whatsapp yang penggunaannya saat ini media sosial tersebut masih banyak digunakan oleh para pemilih pemula. Pemilih pemula dalam penelitian ini berusia antara 18-21 tahun yang merupakan mahasiswa aktif pada Fakultas Ilmu Sosial di Universitas Negeri Semarang.

1. Peran Media Sosial dalam Meningkatkan Partisipasi Pemilih Pemula Mahasiswa FIS UNNES

Penggunaan media sosial,merupakan gambaran penggunaan berbagai aplikasi media sosial dengan mengakses internet di kalangan mahasiswa. Penggunaan berbagai aplikasi media sosial menunjukkan bahwa pengunaan aplikasi Instagram $82,3 \%$ yang paling tinggi diantara aplikasi yang lainnya selanjutnya WhatsApp sebanyak $65,8 \%$, Youtube 47,1\%, Facebook dan Twitter 37,6\%, sedangkan sisanya Line dan Telegram 2,3\%.

Penggunaan aplikasi media sosial dapat dilihat frekuensi dalam mengakses aplikasi media sosial yang ditunjukkan dengan sebanyak $77,6 \%$ mahasiswa lebih memilih untuk membuka aplikasi Instagram dan sebanyak $47 \%$ memilih membuka aplikasi WhatsApp sedangkan sisanya 4,7 \% melalui Youtube, Twitter dan Facebook. Hal ini menunjukkan bahwa frekuensi penggunaan media sosial yang digunakan mahasiswa untuk mendapatkan informasi mengenai pemilihan umum aplikasi pertama yang mereka buka adalah aplikasi Instagram kemudian WhatsApp dan yang terakhir melalui aplikasi Youtube, Twitter dan Facebook.

Isi atau konten kampanye politik yang terdapat di berbagai media lebih menarik apabila ditayangkan melalui media sosial $54,1 \%$ dan sebanyak $43,6 \%$ melalui televisi dan yang terakhir $2,3 \%$ melalui media cetak (koran atau majalah). Hal ini menjadikan media sosial sebagai salah satu produk inovatif di era internet. Maraknya penggunaan media sosial seperti sekarang ini, kampanye politik paling tepat dilakukan melalui media sosial. Menulis status di Facebook atau Twitter yang isinya mempromosikan seorang presiden, sudah dapat dikategorikan berkampanye. Karena status yang ditulis akan dibaca oleh ratusan bahkan ribuan calon pemilih lainnya, yang berpotensi terpengaruh setelah membaca isi status tersebut.

Sedangkan untuk melihat alasan keterlibatan mahasiswa di media sosial sebanyak 94,1 \% menyatakan keterlibatan mereka dengan kesadaran diri sendiri dan sebanyak 9,4\% menyatakan keterlibatan mereka dikarenakan pengaruh dari teman di lingkungan kampus dan tempat tinggal. Hal ini membuktikan bahwa mayoritas mahasiswa memiliki kesadaran yang tinggi dalam pemanfaatan media sosial untuk mendapatkan informasi dan memudahkan berkomunikasi.

Keinginan keterlibatan sebagai pemilih pemula dengan menyebarkan dan mencari informasi terkait dengan pemberitaan pemilu 2019 menunjukkan bahwa $77,6 \%$ menyatakan mahasiswa FIS UNNES berminat untuk terlibat aktif dalam pemberitaan tentang pemilu di media sosial sedangkan sebanyak $7,05 \%$ kurang berminat dan sebanyak 2,3\% mahasiswa tidak 
berminat sama sekali dengan pemberitaan pemilu yang tersebar di media sosial. Hal ini jelas terlihat bahwa mayoritas mahasiswa memiliki minat besar dalam memanfaatkan media sosial untuk mendapatkan pemberitaan tentang pemilu.

Pemanfaatan media sosial sebagai sarana untuk mengakses pengetahuan tentang penyelenggaraan pemilu 2019 sebagai salah satu strategi untuk mencerdaskan mahasiswa yang dalam hal ini pemilih pemula adalah sebanyak $71,7 \%$ menyatakan penting dan sebanyak $28,2 \%$ menyatakan bahwa penyebaran informasi mengenai pemilu di media sosial tidak penting dan mereka tidak tertarik dengan informasi tersebut. Hal ini menunjukkan bahwa sebagian besar mahasiswa merasakan manfaat bahwa melalui media sosial dapat menambah pengetahuan mengenai penyelenggaraan pemilu.

\section{Faktor-Faktor yang Mempengaruhi Partisipasi Pemilih Pemula Mahasiswa FIS UNNES melalui Media Sosial}

Rendahnya tingkat partisipasi politik dalam suatu negara bisa diupayakan meninggi. Ada beberapa pengaruh yang membuat seorang warga memutuskan untuk mengubah keputusannya dari tidak atau enggan untuk berpartisipasi menjadi ikut untuk berpartisipasi. Faktor-faktor inilah yang dapat memicu perubahan tersebut. Menurut Almond (dalam Andriadi, 2016) terdapat tiga pokok penyebab yang dapat memberikan dorongan terhadap keinginan masyarakat untuk berpartisipasi dalam proses pemerintahan, yaitu:

Pertama, modernisasi. Modernisasi memberikan dorongan langsung maupun tidak langsung terhadap partisipasi politik. Modernisasi mengubah berbagai aspek kehidupan masyarakat dalam sebuah negara. Inovasi ini terjadi dalam berbagai aspek yang salah satunya karena dipengaruhi oleh teknologi baru. Tidak dapat dipungkiri dengan hadirnya teknologi-teknologi baru tersebut memberikan kemudahan masyarakat dalam menjalankan aktivitasnya. Termasuk dalam menjalankan aktifitas politiknya yang berupa partisipasi. Semakin mudahnya sistem pemilihan umum ini bisa memicu peningkatan partisipasi.
Kemudahan yang ditawarkan teknologi digital bisa memotivasi warga negara yang sebelumnya tidak berpartisipasi untuk ikut berpartisipasi. Hal ini ditegaskan dengan perolehan sebesar 97,6\% pemilih pemula di lingkungan FIS UNNES memilih untuk menggunakan hak pilihnya pada pemilihan presiden tahun 2019 dan hanya sebanyak 2,3\% memilih untuk tidak menggunakan hak pilihnya dikarenakan salah satunya pemilih pemula tersebut merasa tidak ada tokoh politik yang membawa dengan pasti dan jelas kepentingan rakyat, menurutnya semua tokoh politik tersebut hanya menyampaikan janji-janji belaka.

Kedua, pengaruh kaum intelektual dan komunikasi massa modern. Kaum intelektual memiliki peran besar dalam mendorong partisipasi politik warga negara. Mereka adalah kelompok sosial yang menjadi tolak ukur sikap politik masyarakat umum. Kapasitas keilmuan yang dimiliki kaum intelektual membuat masyarakat umum menjadikannya salah satu rujukan dalam menentukan sikap politik. Masyarakat akan mudah tersugesti untuk mengambil keputusan yang sama dengan kaum intelektual.

Di era teknologi modern saat ini pengaruh kaum intelektual akan sangat gampang menguat ke dalam masyarakat. Tersedianya alat komunikasi, informasi dan interaksi yang lebih canggih membuat kaum intelektual lebih mudah untuk menyampaikan gagasannya secara langsung kepada masyarakat. Dengan memanfaatkan media sosial yang ada seperti Instagram, Facebook, Twitter, seorang intelektual bisa men-share pemikirannya kepada masyarakat secara luas. Tak jarang pemikiran-pemikirannya akan berubah menjadi opini publik. Bahkan lebih hebatnya lagi opini-opini kaum intelektual tersebut yang termuat di media sosial akan diangkat oleh media massa dan menjadikannya sumber berita. Ini bisa terjadi pada masa kampanye pemilihan presiden 2019 melalui media sosial yang dilakukan oleh kaum intelektual yang mempunyai pengaruh kuat dalam meningkatkan partisipasi pemilih pemula, hal ini diperkuat dengan hasil penelitian bahwa sebanyak $63,5 \%$ informasi mengenai pelaksanaan 
pemilu presiden 2019 yang paling banyak diakses oleh pemilih pemula yakni melalui media sosial, dibandingkan dengan media massa atau cetak.

Ketiga, keterlibatan pemerintah dalam urusan sosial, ekonomi dan kebudayaan. Keterlibatan pemerintah dalam berbagai aspek kehidupan warganegara turut mendorong partisipasi politik mereka dalam politik. Kepedulian pemerintah pada rakyat memacu kepedulian rakyat pada politik. Mereka akan merasa perlu dan penting untuk menggunakan hak partisipasi politiknya karena akan mempengaruhi warna pemerintahan. Kehadiran teknologi digital berpengaruh besar terhadap keterlibatan pemerintah dalam urusan sosial, ekonomi, dan kebudayaan. Dengan teknologi digital pemerintah bisa lebih efisien dan efektif dalam mengurus negara.

Kehadiran teknologi digital dalam hal ini khususnya munculnya media sosial telah mengubah pola partisipasi masyarakat. Di era digital partisipasi dapat dilakukan melalui dunia maya. Melalui dunia maya yang tanpa batas, partisipan pemilih pemula menjalankan partisipasi politiknya. Mereka memanfaatkan teknologi digital melalui instagram, facebook, twitter, youtube, whatapp dan yang lainnya sebagai sarana partisipasi politiknya. Fenomena ini mendatangkan era baru partisipasi politik yaitu partisipasi politik digital atau lebih mudahnya kita sebut sebagai partisipasi politik on-line.

DAFTAR PUSTAKA

Andriadi, Fayakhun. 2016. Demokrasi di Tangan Netizen. Jakarta: Semesta Rakyat Merdeka.

Arumsari, Nugraheni. 2018. New Media dan Pengaruhnya dalam Komunikasi Politik Sebagai Upaya Untuk Menciptakan Integrasi Nasional. Seminar Nasional PKn Unnes.

Berger, Charles. 2014, The Handbook Of Communication Science, Bandung: Nusa Media

Lestari, Eta Yuni., Nugraheni Arumsari, Partisipasi Politik Pemilih Pemula Pada Pemilihan Walikota Semarang di Kota Semarang. 2018. Semarang: Unnes Press Littlejohn, Karen A. Foss edisi 2009, Teori Komunikasi. Bandung: Alumni

Nasrullah, R. (2017). Media Sosial: Perspektif Komunikasi, Budaya, dan Sosioteknologi. Bandung: Remaja Rosdakarya.

Sugiyono, (2014). Metode Penelitian Kombinasi (Mix Methodes). Bandung: Penerbit Alfabeta.

Sendjaja, Djuarsa Sasa. 1996. Pengantar Komunikasi. Jakarta: Universitas Terbuka

https://news.detik.com/berita/d-4215354/ada-5 -juta-pemilih-pemula-di-pemilu-2019 